\title{
The Role of Nanosized Gold Particles in Adsorption and Oxidation of Carbon Monoxide over $\mathrm{Au} / \mathrm{Fe}_{2} \mathrm{O}_{3}$ Catalyst
}

\author{
Narendra M Gupta* and Arvind K Tripathi \\ Applied Chemistry Division \\ Bhabha Atomic Research Centre, Trombay, Mumbai-400 085, India \\ *E-mail:nmgupta@magnum.barc.ernet.in
}

Received: 20 August 2001

The presence of gold is found to promote the development of weakly bonded (CO) ad species over the surface of $\mathrm{Au} / \mathrm{Fe}_{2} \mathrm{O}_{3}$ catalyst during interaction with carbon monoxide (CO) or a mixture of carbon monoxide and oxygen. The concentration of these species and the nature of the bonding depend on the gold particle size. No such species are formed for gold particles larger than $-11 \mathrm{~nm}$ or over gold-free iron oxide. The bulk carbonate-like species, formed in the process with the involvement of the hydroxy groups of the support, are merely side products not responsible for the low temperature activity of this catalyst.

Thermochemical measurements reveal that the oxidation of carbon monoxide on both $\mathrm{Fe}_{2} \mathrm{O}_{3}$ and $\mathrm{Au} / \mathrm{Fe}_{2} \mathrm{O}_{3}$ occurs via similar redox mechanisms, involving the abstraction and replenishment of lattice oxygen, where the presence of nanosize gold particles promotes these processes. This is attributed to their capacity to adsorb carbon monoxide because of their inherent defective structural sites. It is suggested that the energy that evolves during chemisorption of $\mathrm{CO}$ is responsible for the surge in temperature at the $\mathrm{Au}-\mathrm{Fe}_{2} \mathrm{O}_{3}$ interfaces, which in turn serve as sites for the accelerated reaction between $\mathrm{CO}$ and the support. The role of gold particle size is discussed in terms of the effect of geometry of surface metal atoms in the nanosize clusters.

The discovery by Haruta et al of the unexpected low temperature $\mathrm{CO}$ oxidation activity of supported gold (1 4) has opened up a new dimension in the understanding of the basics of catalysis, since gold appears to be an exception in disregarding the requirement of unfilled $d$ orbitals for a metal catalysed reaction. Gold, in this new incarnation as a catalyst, has already found application in a number of chemical reactions, such as oxidation (of $\mathrm{CO}, \mathrm{CH}_{4}, \mathrm{CH}_{3} \mathrm{OH}, \mathrm{C}_{6} \mathrm{H}_{6}$, o-hydroxybenzyl alcohol), epoxidation (of propylene), reduction/hydrogenation (of $\mathrm{NO}, \mathrm{CO}$, acetylene, butylene), hydrocracking, water gas shift, and isotopic exchange, etc (See recent reviews and publications 5 - 13). Some practical applications of supported gold include: gas sensors (14), regeneration of $\mathrm{CO}_{2}$ in sealed-off $\mathrm{cw} \mathrm{CO}_{2}$ lasers $(15,16)$ and purification of air (removal of $\mathrm{CO}$ and $\mathrm{VOC}_{\mathrm{s}}$ ) (5). In our laboratory, we have developed a compact low-power long-life sealed-off $\mathrm{cw} \mathrm{CO}_{2}$ laser, where an outer jacket coated with $\mathrm{Au} / \mathrm{Fe}_{2} \mathrm{O}_{3}$ helped in the regeneration of $\mathrm{CO}_{2}$ from the dissociation products $\mathrm{CO}$ and $\mathrm{O}_{2}$ formed during the laser discharge $(15,16)$. The performance of this gold catalyst was found to be superior to that of the other noble metals dispersed on reducible oxide supports (such as $\mathrm{Pt} / \mathrm{SnO}_{2}$ and $\mathrm{Pd} / \mathrm{SnO}_{2}$ ), advocated earlier for this purpose (17). In most of the above-cited applications, the importance of the size of gold crystallites and the nature of the support is generally emphasized. Various issues pertaining to supported gold catalysts, however, still remain unresolved. For instance: what is the role of the gold particle size and what is the optimum size for a particular application? What is the best method of preparing supported gold? What oxidation state of gold is vital to its activity? Does an electronic bonding of the reactants occur at gold sites? What is the nature of the transient species formed in the absence and in presence of gold? Unequivocal answers to these questions are yet to be found.

While the requirement of nanosized gold particles is widely accepted, the actual role of gold as a catalyst and also that of its support in the overall performance have, however, raised many divergent views. Various factors contributing to the high activity of these catalysts are 
envisaged. For instance, the study by Boccuzzi and coworkers $(18,19)$ on gold supported on $\mathrm{ZnO}$ and $\mathrm{TiO}_{2}$ has shown the existence of two kinds of metallic gold sites, which are able to adsorb both oxygen and carbon monoxide at the same time. It has been proposed that the oxidation of carbon monoxide follows two independent pathways; a rapid direct oxidation of $\mathrm{CO}$ at the surface of the metallic particles and a slow induced oxidation with the surface lattice oxygen species of the supports. On the one hand, Haruta et al (2) proposed a reaction mechanism involving the migration of $\mathrm{CO}$ to the metal-support interface and the formation of bidentate carbonate species, where the decomposition of the carbonate-like species is considered to be the ratedetermining step. On the other hand, Bollinger and Vannice (20) demonstrated that the deposition of $\mathrm{TiO}_{\mathrm{x}}$ overlayers onto inactive gold particles produced a highly active catalyst. Furthermore, the bidentate and monodentate carbonates, carboxylates, and formate species formed during exposure of $\mathrm{Au} / \mathrm{TiO}_{2}$ to $\mathrm{CO}$ are thought to be just spectator species playing no role in the oxidation process (20). Knell et al (21), suggest that the high $\mathrm{CO}$ oxidation activity of $\mathrm{Au} / \mathrm{ZrO}_{2}$ arises due to a synergy between the zirconia and the supported gold particles. Unreduced gold species, stabilized by an interaction with the support, are proposed in some studies $(22-24)$ to be more active than $\mathrm{Au}^{0}$.

In a recent publication, Boccuzzi and Chiorino (25) used isotopic oxygen to demonstrate that different reaction channels may operate in $\mathrm{CO}$ oxidation over $\mathrm{Au} / \mathrm{TiO}_{2}$ depending on experimental conditions, such as reaction temperature and presence of moisture. Thus, the reaction at $90 \mathrm{~K}$ was found to occur between preadsorbed $\mathrm{CO}$ molecules with nascent atomic oxygen atoms formed on activation of $\mathrm{O}_{2}$ on gold particles, the process being promoted in the presence of water. On the other hand, a quite extensive exchange reaction occurs with the oxygen atoms of the support at room temperature (25). Tabakova et al (26) conclude that the catalytic activity of gold in the water gas shift depends strongly not only on the dispersion of the gold particles but also on the state and the structure of the support. In addition to the role played by the gold dispersion and the support, the importance of the morphology of gold particles has also been highlighted in some of the studies using various surface characterization techniques (27 31). For instance, the diffuse reflectance Fourier transform infrared study of Baiker and co-workers (31) demonstrated that the nature of gold sites depended upon the support employed. Thus, while the number of low-coordinated gold sites was much higher on $\mathrm{TiO}_{2}$, positively polarized gold atoms existed on $\mathrm{ZrO}_{2}$. The better $\mathrm{CO}$ oxidation activity of $\mathrm{Au} / \mathrm{TiO}_{2}$ compared to that of $\mathrm{Au} / \mathrm{ZrO}_{2}$ is attributed to the gold sites of low coordination, where the weakly bound $\mathrm{CO}$ molecules react with oxygen via an Eley-Rideal type reaction mechanism. The shape rather than the size of crystallites is thus demonstrated to play a more important role in the catalytic activity (31).

The current status of the catalytic properties of gold has been reviewed by Bond and Thompson (5, 32) and also by Kozlov et al (33). A general mechanism involving the oxidation reaction of $\mathrm{CO}$ at the edge of a particle containing both gold atoms and ions and involving the hydroxy groups of the support is invoked by Bond and Thompson (32).

Our motivation to take up this work was based on a realization that many of the previously reported studies, particularly those attempting to establish a structureproperty relationship using surface characterization techniques, were performed under conditions different from that of actual reactions and there is therefore a lack of direct evidence. We at the same time realized that microcalorimetry is a technique sensitive to each step in a catalytic process, and the heat evolved in the reaction therefore represents the overall effect of the processes occurring on the catalyst surface at a particular time. This technique is therefore well suited for the elucidation of transient steps involved in a catalytic process, as has been amply demonstrated in our earlier publications using the catalysts consisting of noble metals on reducible metal oxides as support $(34-37)$. With this in view, we measured enthalpy changes during the adsorption and reaction of $\mathrm{CO}$ or $\mathrm{CO}+\mathrm{O}_{2}$ over $5 \mathrm{at} \% \mathrm{Au} / \mathrm{Fe}_{2} \mathrm{O}_{3}, \mathrm{Fe}_{2} \mathrm{O}_{3}$ and polycrystalline gold samples at different temperatures in the range $300-500 \mathrm{~K}$. The $5 \mathrm{at} \%$ gold on iron oxide catalyst is subsequently referred to as " $\mathrm{Au} / \mathrm{Fe}_{2} \mathrm{O}_{3}$ " throughout the text. The species formed over the surface of these catalysts under similar reaction conditions, and their thermal and time-dependent stability were examined using in situ IR spectroscopy. The highlights of these studies are presented in this article while the detailed results and the experimental procedures are given in our earlier publications $(38,39)$.

\section{RESULTS AND DISCUSSION}

\section{IR Spectra of $\mathrm{Au} / \mathrm{Fe}_{2} \mathrm{O}_{3}$ and $\mathrm{Fe}_{2} \mathrm{O}_{3}$ after Adsorption of CO}

Plots a-c in Figure 1 present the IR spectra of an $\mathrm{Au} / \mathrm{Fe}_{2} \mathrm{O}_{3}$ sample recorded as a function of time after exposure to $13.3 \mathrm{kPa}$ (100 Torr) CO. As seen in this figure, the exposure of a fresh catalyst sample to $\mathrm{CO}$ at room temperature gave rise to a single IR band of 
about $12.6 \mathrm{~cm}^{-1}$ width and at a frequency of $-2107 \mathrm{~cm}^{1}$. No side bands were observed. Several overlapping bands due to oxygenated species (1100$1700 \mathrm{~cm}^{-1}$ ) and the IR bands in the 2300-2400 $\mathrm{cm}^{-1}$ region due to $v_{3}$ vibrations of $\mathrm{CO}_{2}$, produced in the process, may also be seen in this figure. As indicated by absorbance values, given in parentheses, the intensity of the $v(\mathrm{CO})$ band decreased progressively with increasing contact time while the intensity of the IR bands due to oxygenated species increased (Figure 1b, c). Also, an increase of 2-3 $\mathrm{cm}^{-1}$ in the frequency of this band was observed after about $1 \mathrm{~h}$ (Figure 1c). While the intensity of the various bands mentioned above increased with pressure, their frequency always remained unchanged. We may mention that oxygenate species similar to those shown in Figure $1(\mathrm{a}-\mathrm{c})$ were also formed during exposure to $\mathrm{CO}_{2}$. For a comparison, curve d in Figure 1 is the IR spectrum of $\mathrm{Au} / \mathrm{Fe}_{2} \mathrm{O}_{3}$ after exposure to 13.3 $\mathrm{kPa} \mathrm{CO}$ at room temperature. The intensity of these bands decreased progressively on increase in catalyst temperature and also on post-exposure annealing of the sample. A complete removal of these species was observed only at temperatures above $475 \mathrm{~K}$ (40).

The width of the $v(\mathrm{CO})$ band increased considerably when an $\mathrm{Au} / \mathrm{Fe}_{2} \mathrm{O}_{3}$ sample was used repeatedly for $\mathrm{CO}$ adsorption, pretreated each time under $\mathrm{O}_{2}$ at $570 \mathrm{~K}$ and followed by evacuation at the same temperature. The shape of the band thus obtained could be resolved into at least three well-fitted

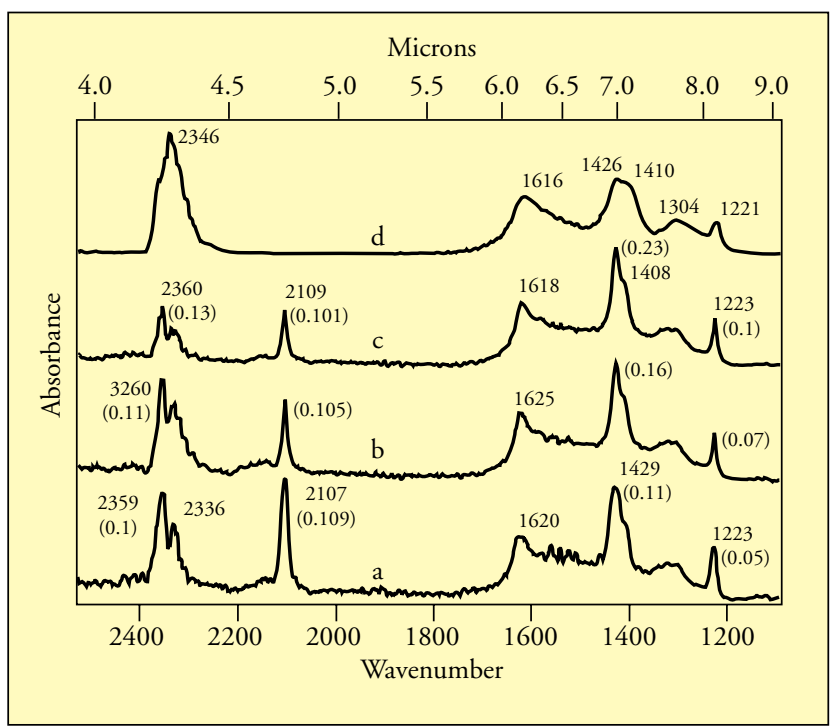

Figure 1 Development of IR spectra as a function of time on exposure of an $\mathrm{Au} / \mathrm{Fe}_{2} \mathrm{O}_{3}$ catalyst to 100 Torr $\mathrm{CO}$ at room temperature. a) $5 \mathrm{~min}$, b) $30 \mathrm{~min}$, and c) $1 \mathrm{~h}$. Spectrum dis for an $\mathrm{Au} / \mathrm{Fe}_{2} \mathrm{O}_{3}$ sample exposed at room temperature to 100 Torr $\mathrm{CO}_{2}$
Gaussian-shaped bands having maxima at around 2090,2110 , and $2130 \mathrm{~cm}^{-1}$, indicating the existence of some new adsorption sites (40).

\section{Adsorption of Isotopic CO}

Figure 2 gives the IR spectra of $\mathrm{Au} / \mathrm{Fe}_{2} \mathrm{O}_{3}$, developed on adsorption of isotopic $\mathrm{CO}\left({ }^{13} \mathrm{C}^{16} \mathrm{O}\right.$ and $\left.{ }^{12} \mathrm{C}^{18} \mathrm{O}\right)$ at 300 $\mathrm{K}$. A uniform shift of all $v(\mathrm{CO})$ bands was observed so that the frequency ratio $\left(\nu_{\text {isotopic }} / \nu_{\text {normal }}\right)$ for an individual band was always $\sim 0.977$, as was confirmed by the computer resolution of these bands. On the other hand, the individual oxygenate-region bands showed different shifts for isotopic gases. Thus the bands at 1618, 1430 and $1410 \mathrm{~cm}^{-1}$ showed a red shift with $\Delta v$ of 46,35 and $20 \mathrm{~cm}^{-1}$ respectively, corresponding to a ${ }^{13} \mathrm{C} /{ }^{12} \mathrm{C}$ ratio of around $0.972,0.979$ and 0.986 respectively. No shift was however observed in the $1223 \mathrm{~cm}^{-1}$ band (Figure $2 \mathrm{~b}$ ). Very similar behaviour was observed for the adsorption of ${ }^{12} \mathrm{C}^{18} \mathrm{O}$. In this case the frequency of $v(\mathrm{CO})$ band at $2107 \mathrm{~cm}^{-1}$ shifted to a lower frequency of $2063 \mathrm{~cm}^{-1}$. The prominent oxygenate region bands at 1620 and $1430 \mathrm{~cm}^{-}$ ${ }^{1}$ showed a red shift of about 12 and $7 \mathrm{~cm}^{-1}$, respectively.

\section{Adsorption on $\mathrm{Fe}_{2} \mathrm{O}_{3}$ and Effect of Calcination}

No $v(\mathrm{CO})$ bands and only $v\left(\mathrm{CO}_{2}\right)$ and carbonate region bands were observed on adsorption of $\mathrm{CO}$ over $\mathrm{Fe}_{2} \mathrm{O}_{3}$ irrespective of catalyst temperature or $\mathrm{CO}$ gas pressure. On calcination of $\mathrm{Au} / \mathrm{Fe}_{2} \mathrm{O}_{3}$ at higher temperature, the intensity of the $v(\mathrm{CO})$ band and that

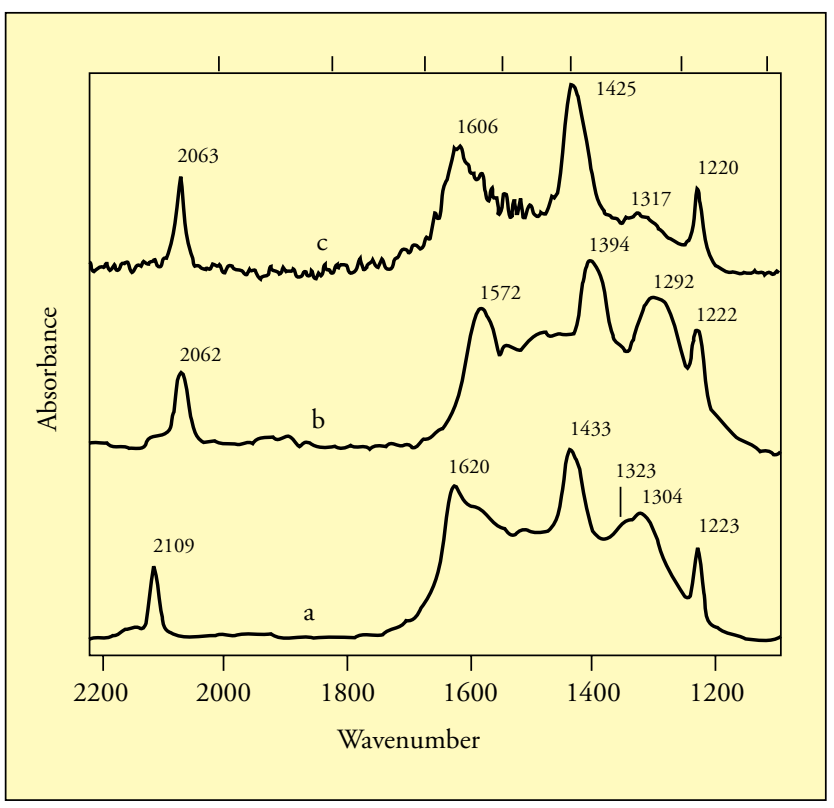

Figure 2 Development of vibrational bands on $\mathrm{Au} / \mathrm{Fe}_{2} \mathrm{O}_{3}$ catalyst after exposure to a) 50 Torr ${ }^{12} \mathrm{C}^{16} \mathrm{O}$, b) 50 Torr ${ }^{13} \mathrm{C}^{16} \mathrm{O}$ and c) 20 Torr ${ }^{12} \mathrm{C}^{18} \mathrm{O}$ 


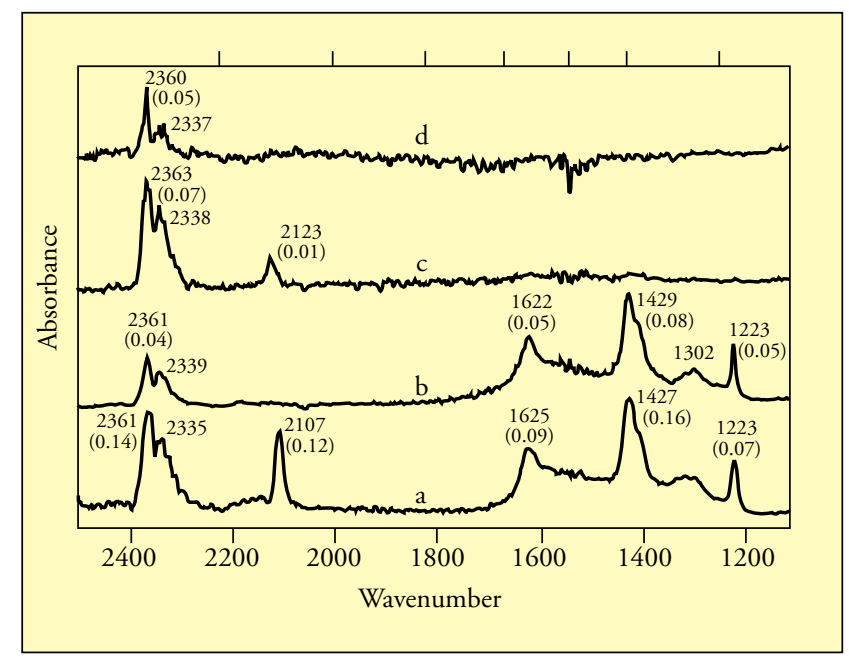

Figure $3 \mathrm{IR}$ bands developed on $\mathrm{Au} / \mathrm{Fe}_{2} \mathrm{O}_{3}$ (a) and $\mathrm{Fe}_{2} \mathrm{O}_{3}$ (b) catalysts after exposure to 100 Torr $\mathrm{CO}$ at $300 \mathrm{~K}$. Spectra $c$ and d are for $\mathrm{Au} / \mathrm{Fe}_{2} \mathrm{O}_{3}$ samples calcined at 820 and $870 \mathrm{~K}$, respectively. Numbers in parentheses indicate the absorbance values (Reproduced from J.Catal., 1999, 187, 332 with the permission of Academic Press)

of the IR bands due to oxygenate species and $\mathrm{CO}_{2}$ were much lower. Figure 3 gives comparative infrared bands developed on $\mathrm{Au} / \mathrm{Fe}_{2} \mathrm{O}_{3}$ and $\mathrm{Fe}_{2} \mathrm{O}_{3}$ samples as a function of calcination temperature. No bands were formed in the oxygenate region when $\mathrm{CO}$ was adsorbed at room temperature over an $\mathrm{Au} / \mathrm{Fe}_{2} \mathrm{O}_{3}$ sample calcined at 820 or $870 \mathrm{~K}$ (Figure 3c, d), even though a comparable amount of $\mathrm{CO}_{2}$ still formed ( $c$ Figure $3 \mathrm{c}$ ).

Calcination of $\mathrm{Au} / \mathrm{Fe}_{2} \mathrm{O}_{3}$ resulted in a progressive increase in gold particle size, as evaluated by TEM (38). For a calcination temperature of $673 \mathrm{~K}$, about $75 \%$ of gold particles were in the $3-5 \mathrm{~nm}$ range, while the average size was around $4.8 \mathrm{~nm}$. The calcination of a sample at $873 \mathrm{~K}$ resulted in gold particles of $5-20 \mathrm{~nm}$ size, the average being $\sim 11 \mathrm{~nm}$.

\section{Effect of CO Adsorption and Calcination on Hydroxy Region Bands}

The experiments performed with both $\mathrm{Fe}_{2} \mathrm{O}_{3}$ and $\mathrm{Au} / \mathrm{Fe}_{2} \mathrm{O}_{3}$ showed that the intensity of the hydroxyl group stretching bands at 3628 and $3665 \mathrm{~cm}^{-1}$ decreased considerably on adsorption of $\mathrm{CO}$ at room temperature. For exposures of $\mathrm{CO}$ at higher temperatures, $\mathrm{OH}$ groups were removed very quickly and no bands were detected in this region. These data are shown in Figure 4 for adsorption of $\mathrm{CO}$ on $\mathrm{Fe}_{2} \mathrm{O}_{3}$ at two different temperatures.

The intensity of the $v(\mathrm{OH})$ region bands was again found to decrease substantially on calcination of a sample at temperatures in range 800-900 K (40).

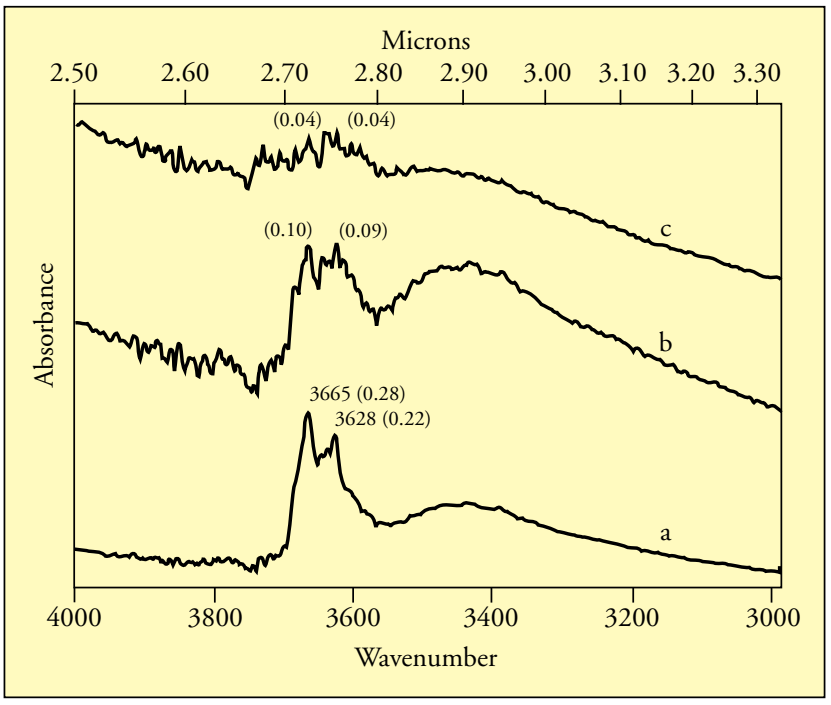

Figure 4 Hydroxyl region bands of $\mathrm{Fe}_{2} \mathrm{O}_{3}$ after adsorption of 100 Torr $C O$ at different temperatures. a) no CO, b) $300 \mathrm{~K}$ and c) $370 \mathrm{~K}$. Numbers in parentheses indicate the absorbance values

\section{Adsorption of $\mathrm{CO}+\mathrm{O}_{2}$}

Behaviour similar to that of $v(\mathrm{CO}), v\left(\mathrm{CO}_{2}\right)$ and oxygenate region bands shown in Figures 1, 2 and 3 was also observed for exposures of $\mathrm{CO}+\mathrm{O}_{2}$, even though their intensities varied marginally. These data are included in an earlier publication (38).

\section{Catalytic Activity}

The $\mathrm{Au} / \mathrm{Fe}_{2} \mathrm{O}_{3}$ catalyst calcined in air at $673 \mathrm{~K}$ showed considerable activity at $273 \mathrm{~K}$ for the $\mathrm{CO}$ oxidation reaction, the percentage conversion of $\mathrm{CO}$ to $\mathrm{CO}_{2}$ being around $50 \%$ when a reaction mixture consisting of $\mathrm{CO}+\mathrm{O}_{2}+\mathrm{He}(2: 1: 17)$ was employed at a flow rate of $1.2 \mathrm{Lh}^{-1} \mathrm{~g}^{-1} \cdot 100 \%$ conversion was observed during the reaction at room temperature or above (Figure 5a). The catalytic activity remained unchanged during $40 \mathrm{~h}$ on stream.

Both $\mathrm{Fe}_{2} \mathrm{O}_{3}$ and polycrystalline gold powder showed poor activity as compared with $\mathrm{Au} / \mathrm{Fe}_{2} \mathrm{O}_{3}$ and the reaction onset temperature in these cases was more than $373 \mathrm{~K}$. In the case of $\mathrm{Fe}_{2} \mathrm{O}_{3}, 100 \%$ conversion of $\mathrm{CO}$ was observed only at temperatures above $473 \mathrm{~K}$ under identical reaction conditions. Curves $\mathrm{b}$ and $\mathrm{c}$ in Figure 5 show the temperature-dependent catalytic activity of $\mathrm{Fe}_{2} \mathrm{O}_{3}$ and polycrystalline gold samples.

Calcination of $\mathrm{Au} / \mathrm{Fe}_{2} \mathrm{O}_{3}$ at temperatures above $850 \mathrm{~K}$ resulted in a steady decrease in catalytic activity. Curves $\mathrm{d}$ and $\mathrm{e}$ in Figure 5 indicate typical activity data for samples calcined at 870 and $970 \mathrm{~K}$, respectively. 


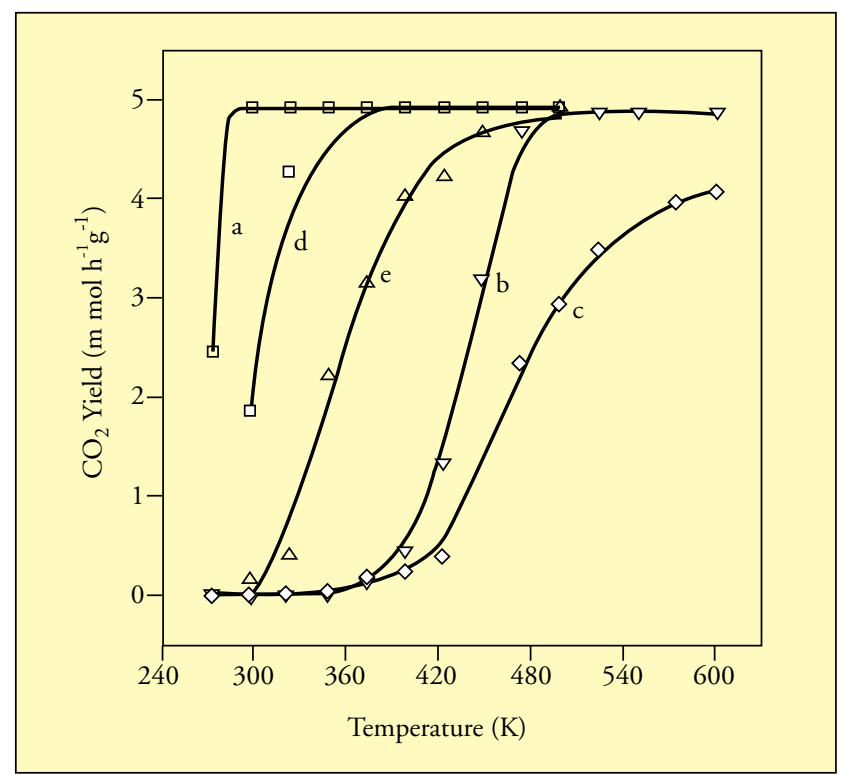

Figure $5 \mathrm{CO}$ oxidation activity at different reaction temperatures of $\mathrm{Au} / \mathrm{Fe}_{2} \mathrm{O}_{3}(\mathrm{a}), \mathrm{Fe}_{2} \mathrm{O}_{3}$ (b) and polycrystalline gold (c) calcined at $670 \mathrm{~K}$. Curves d and e show corresponding data for an $\mathrm{Au} / \mathrm{Fe}_{2} \mathrm{O}_{3}$ sample calcined at 870 and $970 \mathrm{~K}$, respectively

\section{THERMOCHEMICAL DATA}

Adsorption of $\mathrm{CO}$ and $\mathrm{O}_{2}$ from a $\mathrm{CO}+\mathrm{O}_{2}$ pulse

Data given in Figure 6 show the fraction of $\mathrm{CO}$ and $\mathrm{O}_{2}$ adsorbed/reacted (average value from 5 to 6 successive pulse exposures) when an $\mathrm{Au} / \mathrm{Fe}_{2} \mathrm{O}_{3}$ sample was exposed to a $4.1 \mu \mathrm{mol}$ pulse of $\mathrm{CO}+\mathrm{O}_{2}(2: 1)$ at different temperatures. At 300 and $330 \mathrm{~K}$ the amount of $\mathrm{CO}$ adsorbed/reacted was marginally higher than that of $\mathrm{O}_{2}$. Thus, the fractions of $\mathrm{CO}$ and $\mathrm{O}_{2}$ adsorbed from a pulse were about 60 and $51 \%$ respectively at a reaction temperature of $300 \mathrm{~K}$. This gap decreased progressively with increasing temperature, and at temperatures above $330 \mathrm{~K}$ almost identical fractions of $\mathrm{CO}$ and $\mathrm{O}_{2}$ were adsorbed/reacted from a pulse (Figure 6a, b).

\section{$\mathrm{CO}_{2}$ yield}

The amount of $\mathrm{CO}_{2}$ produced from a pulse also increased progressively with a rise in catalyst temperature as shown by data in Figure 6c. Thus, while about $70 \%$ of $\mathrm{CO}$ adsorbed from a pulse was converted to $\mathrm{CO}_{2}$ at $470 \mathrm{~K}$, the yield of $\mathrm{CO}_{2}$ from $\mathrm{CO}_{\mathrm{ad}}$ was negligibly small at room temperature.

\section{Enthalpy Changes}

Curve $\mathrm{d}$ in Figure 6 presents the temperature dependence of the amount of heat evolved per mol $\left(\mathrm{Q}_{\text {molar }}\right)$ when a
$\mathrm{CO}+\mathrm{O}_{2}$ pulse was dosed over a catalyst sample. A

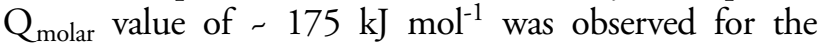
exposure of $4.1 \mu \mathrm{mol} \mathrm{CO}+\mathrm{O}_{2}$ at room temperature. The value increased marginally to $210 \mathrm{~kJ} \mathrm{~mol}^{-1}$ for an experiment at $330 \mathrm{~K}$ and then decreased again with further increase in catalyst temperature (Figure 6d).

\section{$\mathrm{Fe}_{2} \mathrm{O}_{3}$ Catalyst}

Similar but much smaller fractions of $\mathrm{CO}$ or $\mathrm{O}_{2}$ were adsorbed/reacted when $\mathrm{CO}+\mathrm{O}_{2}$ (2:1) pulses (4.1 $\mu$ mol each) were dosed over an $\mathrm{Fe}_{2} \mathrm{O}_{3}$ sample at different temperatures. Thus, only -5 to $6 \%$ of $\mathrm{CO}$ and 3 to $4 \%$ of $\mathrm{O}_{2}$ were adsorbed/reacted for exposures at temperatures of 300 or $330 \mathrm{~K}$. These values increased progressively with the rise in sample temperature, the adsorbed fraction being $-55 \%$ at a reaction temperature of $470 \mathrm{~K}$. Curves $\mathrm{a}$ and $\mathrm{b}$ in Figure 7 indicate the average amount of $\mathrm{CO}$ and $\mathrm{O}_{2}$ adsorbed/reacted from 5 - 6 successive pulse exposures at different sample temperatures. Correspondingly, a negligible amount of $\mathrm{CO}_{2}$ was formed at temperatures below $400 \mathrm{~K}$ (Figure $7 \mathrm{c}$ ), whereas at higher reaction temperatures the yield of $\mathrm{CO}_{2}$ was almost similar to that shown in Figure 6c.

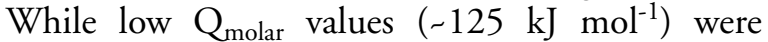
observed for reaction at 330 and $370 \mathrm{~K}$, the average

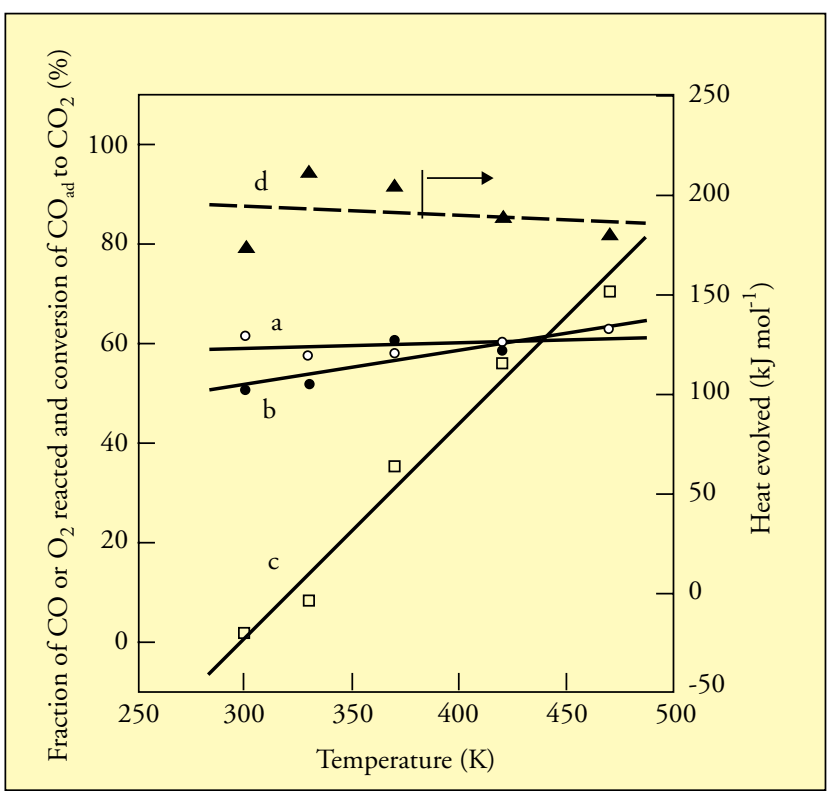

Figure 6 Average fraction of $\mathrm{CO}(\mathrm{a})$ and $\mathrm{O}_{2}(\mathrm{~b})$ adsorbed/reacted when 4.1 umol $\mathrm{CO}+\mathrm{O}_{2}(2: 1)$ pulses were dosed over $\mathrm{Au} / \mathrm{Fe}_{2} \mathrm{O}_{3}$ catalyst at different temperatures. Curve (c) shows the conversion of $\mathrm{CO}_{\text {ad }}$ to $\mathrm{CO}_{2}$ and curved presents the data on the heat evolved in the process. (Reproduced from J. Catal., 1999, 187, 332 with the permission of Academic Press) 
values were around 200 and $190 \mathrm{~kJ} \mathrm{~mol}^{-1}$ for the interaction of $\mathrm{CO}+\mathrm{O}_{2}$ at 420 and $470 \mathrm{~K}$, respectively (Figure $7 \mathrm{~d}$ ).

\section{Gold Catalyst}

No measurable amount of $\mathrm{CO}$ or $\mathrm{O}_{2}$ was adsorbed/reacted when a polycrystalline gold powder was exposed to $\mathrm{CO}+\mathrm{O}_{2}$ pulses at temperatures below 370 $\mathrm{K}$. Even at the higher reaction temperatures of this study, smaller fractions of both $\mathrm{CO}$ and $\mathrm{O}_{2}$ were adsorbed as compared with the $\mathrm{Au} / \mathrm{Fe}_{2} \mathrm{O}_{3}$ catalysts, as is shown in the data of Figures 8a, b. Correspondingly, no $\mathrm{CO}_{2}$ was formed at reaction temperatures below $370 \mathrm{~K}$, whereas at temperatures above $400 \mathrm{~K}$ a complete transformation of $\mathrm{CO}_{a d}$ to $\mathrm{CO}_{2}$ was observed (Figure 8c).

Curve $\mathrm{d}$ in Figure 8 presents the average $\mathrm{Q}_{\text {molar }}$ values for adsorption of $\mathrm{CO}+\mathrm{O}_{2}$ over a gold sample at different temperatures. A negligible amount of heat was evolved for reaction temperatures below $370 \mathrm{~K}$, commensurate with the amounts of $\mathrm{CO} / \mathrm{O}_{2}$ adsorbed. Also, the $\mathrm{Q}_{\text {molar }}$ values for gold (Figure $8 \mathrm{~d}$ ) are comparatively lower than the corresponding data in Figures 6 and 7.

\section{Rise of Catalyst Bed Temperature During $\mathrm{CO}+\mathrm{O}_{2}$ Reaction}

Precise measurements indicated that the bulk temperature of $\mathrm{Au} / \mathrm{Fe}_{2} \mathrm{O}_{3}$ catalyst increased almost

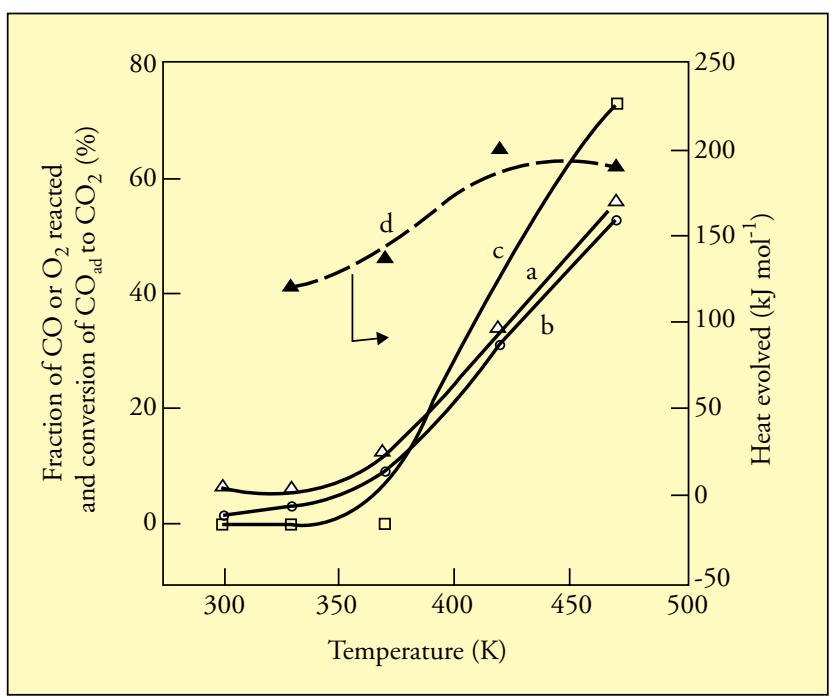

Figure 7 Average fraction of $\mathrm{CO}(\mathrm{a})$ and $\mathrm{O}_{2}(\mathrm{~b})$ adsorbed/ reacted and conversion of $\mathrm{CO}_{a d}$ to $\mathrm{O}_{2}$ (curve c) when 4.1 umol pulses of $\mathrm{CO}+\mathrm{O}_{2}(2: 1)$ were injected over $\mathrm{Fe}_{2} \mathrm{O}_{3}$ catalyst at different temperatures. Curve (d) gives the heat evolved in the process. (Reproduced from J. Catal., 1999, 187, 332 with the permission of Academic Press)

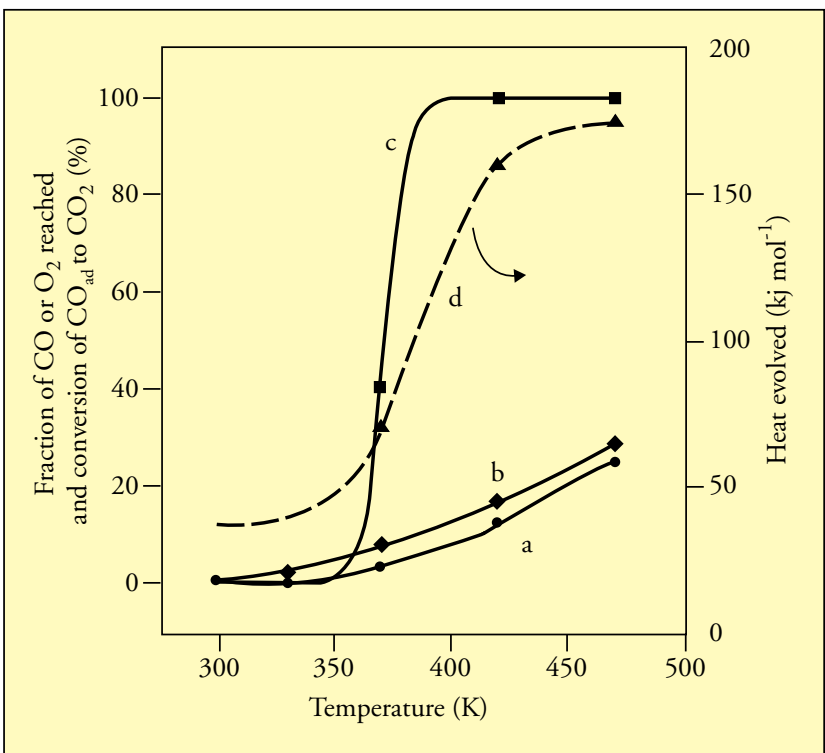

Figure 8 Average fraction of $\mathrm{CO}(\mathrm{a})$ and $\mathrm{O}_{2}(\mathrm{~b})$ adsorbed/ reacted and conversion of $\mathrm{CO}_{\text {ad }}$ to $\mathrm{CO}_{2}$ (curve c) when 4.1 umol pulses of $\mathrm{CO}+\mathrm{O}_{2}$ (2:1) were injected over polycrystalline gold powder at different temperatures. Curve (d) gives the heat evolved in the process. (Reproduced from J. Catal., 1999, 187, 332 with the permission of Academic Press)

instantly when the catalyst maintained at room temperature was exposed to a $\mathrm{CO}+\mathrm{O}_{2}$ flow and the extent of this rise depended on the calcination temperature to which the catalyst was subjected before the $\mathrm{CO}+\mathrm{O}_{2}$ flow commenced. Thus, a rise of $\sim 12 \mathrm{~K}$ in catalyst bulk temperature was observed for the sample calcined below $700 \mathrm{~K}$. The corresponding rise was about 10 and $5 \mathrm{~K}$ for the samples pretreated at 773 and $873 \mathrm{~K}$ respectively. Furthermore, no rise in catalyst bulk temperature was observed when a sample calcined at $973 \mathrm{~K}$ was exposed to $\mathrm{CO}+\mathrm{O}_{2}$ flow at 298 $\mathrm{K}$. Also, no measurable temperature rise was detected for the experiments performed at higher reaction temperatures and also for the $\mathrm{CO}+\mathrm{O}_{2}$ reaction over $\mathrm{Fe}_{2} \mathrm{O}_{3}$ or gold powder at the reaction temperatures used in this study. The temperature rise, as mentioned above, remained unchanged during a run time of 5 to $6 \mathrm{~h}$. These data are given in Table 1.

We interpret our results as follows:

1 The adsorption of $\mathrm{CO}$ is facilitated by the presence of gold (Figures 1 - 3). However, the isotopic shift of -0.977 in the $v(\mathrm{CO})$ bands (Figure 3) corresponds to the shift expected for gaseous $\mathrm{CO}$ as per the Redlich-Teller rule, and therefore indicates only a weak Au-CO bonding where bonded carbon monoxide retained its gaseous 
Table 1 Temperature Rise of a 5 at $\% \mathrm{Au}_{\mathrm{Fe}} \mathrm{O}_{3}$ Catalyst Bulk, Subjected to Calcination at Different Temperatures and Exposed at $298 \mathrm{~K}$ to a $\mathrm{CO}+\mathrm{O}_{2}+\mathrm{He}(2: 1: 17)$ Stream $\left(50 \mathrm{ml} \mathrm{min}^{-1}\right)$

\begin{tabular}{cccc} 
Calcination & $\begin{array}{c}\text { Initial Temperature Rise, K } \\
\text { (within 2-5 min) }\end{array}$ & $\begin{array}{c}\text { Equilibrium Temperature } \\
\text { Rise after } \mathbf{5} \text { h Test Run, K }\end{array}$ \\
\hline & 673 & 12 & 10 \\
3 & 773 & 10 & 8 \\
4 & 873 & 5 & 5 \\
\end{tabular}

character. This observation finds support from a study of Grunwaldt et al (31), who demonstrated that $\mathrm{CO}$ adsorption was reversible on supported gold catalysts and the weaker $\mathrm{CO}$ bonding led to a more active catalyst. Also, the presence of weak side bands (Figure 1) particularly on samples used repeatedly for $\mathrm{CO}$ oxidation, reveals the formation of a small number of $\mathrm{Au}(\mathrm{CO}) \mathrm{O}$ species. Since the oxidative pretreatments of supported catalysts are known to improve the metal dispersion further $(41-43)$, it is likely that such co-adsorbed species are formed only over very small gold particles.

2 Figure 3 (c, d) shows that no carbonate-type species were formed by interaction with the $\mathrm{CO}$ (or $\mathrm{CO}+$ $\left.\mathrm{O}_{2}\right)$ in the case of calcined $\mathrm{Au} / \mathrm{Fe}_{2} \mathrm{O}_{3}$ or $\mathrm{Fe}_{2} \mathrm{O}_{3}$ samples that are devoid of hydroxy groups (Figure 4), even though the formation of $\mathrm{CO}_{2}$ occurred. It is thus apparent that the $\mathrm{OH}$ groups are important for the formation of oxygenates through reaction with product $\mathrm{CO}_{2}$, rather than in the $\mathrm{CO}+\mathrm{O}_{2}$ reaction as envisaged by some authors (32). This is in agreement with the observed formation of identical carbonate-like species during interaction of $\mathrm{CO}_{2}$ with $\mathrm{Au} / \mathrm{Fe}_{2} \mathrm{O}_{3}$ (Figure 1d) and also with $\mathrm{Fe}_{2} \mathrm{O}_{3}(40)$ at different temperatures in range $295-475 \mathrm{~K}$.

3 Based on the results for adsorption of isotopic gases (Figure 2), the $\mathrm{CO}$ or $\mathrm{CO}_{2}$ formed during its oxidation give rise to formation of the following bulk oxygenate species (44):

(i) Bicarbonate species (1614 - 1620, 1407 and $1223 \mathrm{~cm}^{-1}$ bands) - formed at room temperature and below:<smiles>OC(=[18O])O[18OH]</smiles><smiles>[18O]=C([18OH])O[18OH]</smiles>

(ii) Monodentate carbonate (1430, 1300 - 1320 $\mathrm{cm}^{-1}$ ) - formed at room temperature and below:<smiles></smiles>

(iii) Bidentate carbonates or adsorbed $\mathrm{CO}_{2}$ species $\left(1510,1340 \mathrm{~cm}^{-1}\right)$ - formed only at elevated temperatures $(>350 \mathrm{~K})$ :<smiles></smiles>

The temperature-dependent variation in intensity has demonstrated that the species (i) and (ii) shown earlier are fairly stable below $450 \mathrm{~K}$, both under ambient pressure and under pumping conditions $(38,40)$. In agreement with the study of Vannice et al (20) we may therefore infer that such species may not play an important role in $\mathrm{CO}_{2}$ formation, particularly at low reaction temperatures.

4 A comparison between the data in Figures 6 and 7 shows that the presence of gold resulted in the augmented adsorption/reaction of both $\mathrm{CO}$ and $\mathrm{O}_{2}$ and in the higher conversion of adsorbed $\mathrm{CO}$ to $\mathrm{CO}_{2}$, particularly at reaction temperatures lower than $450 \mathrm{~K}$. The enthalpy data of our study suggest the preponderance of a normal redox mechanism, $i e$ via lattice oxygen abstraction, for both the $\mathrm{Fe}_{2} \mathrm{O}_{3}$ and $\mathrm{Au} / \mathrm{Fe}_{2} \mathrm{O}_{3}$ catalysts. Thus, the $\mathrm{Q}_{\text {molar value of }}$ 175 to $200 \mathrm{~kJ} \mathrm{~mol}^{-1}$ in Figure 6 can be attributed to the simultaneous occurrence of reactions IV and V (Table 2), where Step IV may play a greater role because of larger $\mathrm{CO}$ adsorption. In the case of the $\mathrm{Fe}_{2} \mathrm{O}_{3}$ sample, almost the same $\mathrm{Q}_{\text {molar }}$ values are observed at reaction temperatures above $400 \mathrm{~K}$ (Figure 7). At lower reaction temperatures, the 
amount of $\mathrm{CO}$ adsorbed is marginally higher than that of $\mathrm{O}_{2}$ and therefore a lower $\mathrm{Q}_{\text {molar }}(-120-130$ $\mathrm{kJ} \mathrm{mol}^{-1}$ ) value at temperatures below $400 \mathrm{~K}$ (Figure 7) may be ascribed to a greater role for reaction Step IV (Table 2). Our thermochemical data show that, contrary to prevailing views, a Langmuir-Hinshelwood type mechanism involving $\mathrm{CO}_{(\mathrm{ad})}+\mathrm{O}_{(\mathrm{ad})}$ reaction may not play an important role with the supported gold catalyst (see Table 2 ), at least at room temperature and above. The heat values observed for the polycrystalline gold sample, on the other hand, suggest that the reaction mechanism in the case of $\mathrm{CO}$ oxidation over pure gold depends upon the catalyst temperature. Thus, while at lower reaction temperature $\mathrm{CO}_{\mathrm{ad}}+\mathrm{O}_{\mathrm{ad}}$ (Reaction III, Table 2) governs the CO oxidation explaining the lower $\mathrm{Q}_{\text {molar }}$ values, the value of Qmolar $-200 \mathrm{~kJ} \mathrm{~mol}^{-1}$ at higher temperatures corresponds to $\mathrm{CO}_{(\mathrm{g})}+\mathrm{O}_{(\mathrm{ad})}$ process (Reaction II, Table 2).

The above points thus clearly indicate that the reaction mechanism of $\mathrm{CO}$ oxidation on $\mathrm{Au} / \mathrm{Fe}_{2} \mathrm{O}_{3}$ catalyst is quite different from that on metallic gold. A comparison of data in Figures 6 and 7 shows that the presence of gold-promoted adsorption of $\mathrm{CO}$ and $\mathrm{O}_{2}$ to an almost equal extent lowers the reaction temperature for the $\mathrm{CO}$ oxidation reaction.

As has been brought out in detail in our earlier publications $(38,39)$, gold may augment the $\mathrm{CO}$ oxidation activity of $\mathrm{Fe}_{2} \mathrm{O}_{3}$ (Figure 5) in the following two possible ways:

i) $\mathrm{CO}$ or $\mathrm{O}_{2}$ molecules on activation at Au sites may spill over to adjacent $\mathrm{Fe}_{2} \mathrm{O}_{3}$ sites leading to higher activity, and

ii) The energy released in the chemisorption of $\mathrm{CO}$ or $\mathrm{O}_{2}$ molecules over $\mathrm{Au}$ sites may give rise to a localized energy surge and hence to a temperature rise in the neighbouring lattice regions where the $\mathrm{Fe}_{2} \mathrm{O}_{3}+\mathrm{CO}$ reaction may occur at an accelerated rate.

The concept of localized thermal surge at metal/support interfaces as advocated in reference 38, is in complete harmony with the observations of the present study. This is in accordance with the data in Table 1 showing that the temperature of the catalyst bed increased by $-10-15 \mathrm{~K}$ when a $\mathrm{CO}+\mathrm{O}_{2}(2: 1)$ gas stream was passed over $\mathrm{Au} / \mathrm{Fe}_{2} \mathrm{O}_{3}$ catalyst at room temperature in the flow through mode. The actual temperature rise at the metal/support interfaces may be still higher, and that would result in accelerated $\mathrm{CO}+\mathrm{O}_{2}$ reaction at these specific sites.

\section{CONCLUSIONS}

We thus suggest that a possible explanation for the synergistic catalytic activity of $\mathrm{Au} / \mathrm{Fe}_{2} \mathrm{O}_{3}$ for the $\mathrm{CO}$ oxidation reaction is the transfer of chemisorption energy from the metal particle to the support thus leading to a localized temperature surge at the metal/ support interface, which may act as the sites of higher CO oxidation activity. Being restricted to metal/support interfaces at microscopic level, the bulk temperature of the catalyst may be affected only marginally, as has been observed in our study.

Table 2 Estimated Values of Heat Evolution for the Possible Reactions Occurring on the Au/Fe $\mathrm{O}_{3}$ Catalyst Surface During CO Oxidation Reaction: see reference 38

I. Direct reaction of $\mathrm{CO}$ and $\mathrm{O}$ at gold sites

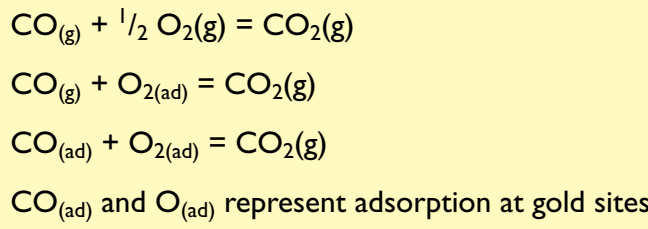

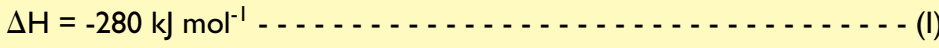

$\Delta \mathrm{H}=-230 \mathrm{~kJ} \mathrm{~mol}^{-1}$ at $300 \mathrm{~K} \&-200 \mathrm{~kJ} \mathrm{~mol}^{-1}$ at $470 \mathrm{~K} \ldots \ldots$

$\Delta \mathrm{H}=-150 \mathrm{~kJ} \mathrm{~mol}^{-1}$ at $300 \mathrm{~K}$

2. Redox mechanism involving lattice oxygen of support

$$
\begin{array}{ll}
\mathrm{CO}_{(\mathrm{g})}+3 \mathrm{Fe}_{2} \mathrm{O}_{3}=2 \mathrm{Fe}_{3} \mathrm{O}_{4}+\mathrm{CO}_{2}(\mathrm{~g}) & \Delta \mathrm{H}=-48.3 \mathrm{~kJ} \mathrm{~mol}^{-1} \\
4 \mathrm{Fe}_{3} \mathrm{O}_{4}+\mathrm{O}_{2}=6 \mathrm{Fe}_{2} \mathrm{O}_{3} & \Delta \mathrm{H}=-465 \mathrm{~kJ} \mathrm{~mol}^{-1}
\end{array}
$$

\section{Secondary Reactions}

$\mathrm{CO}_{2}+\mathrm{Fe}_{2} \mathrm{O}_{3} \rightarrow$ Carbonate-like species, such as carbonates, bicarbonates, formates etc

$$
\Delta \mathrm{H}=-75 \mathrm{~kJ} \mathrm{~mol}^{-1} \text { at } 300 \mathrm{~K} \text { and }-90 \mathrm{~kJ} \mathrm{~mol}^{-1} \text { at } 470 \mathrm{~K} \text { - }
$$


The data in Figures 1 and 3 clearly reveal that the mode of CO chemisorption depended on the size of gold particles, which in turn is sensitive to the pretreatment conditions used for a sample. Our X-ray photoelectron spectroscopy studies (40) showed that no ionic gold species may exist to a significant extent, both prior to and after using an $\mathrm{Au} / \mathrm{Fe}_{2} \mathrm{O}_{3}$ catalyst for $\mathrm{CO}$ oxidation. Several other studies have reported similar observations $(31,45,46)$. The particle size effect in the catalytic properties of gold may therefore have its origin in the effects of geometry controlled by crystallographic characteristics of the faces exposed (47) rather than in the modified electronic properties of gold. The concentration and the nature of geometric defects are known to be dependent on particle size and these in turn are known to control the catalytic properties (48).

\section{ABOUT THE AUTHORS}

Dr N M Gupta obtained his PhD in Chemistry at Agra University and joined Bhabha Atomic Research Centre, Mumbai, India in 1966. He is Head of the Applied Chemistry Division at BARC and is involved in basic research and development activities in catalysis, surface science and solid state chemistry. $\mathrm{He}$ has 100 publications and two edited books to his credit.

A K Tripathi obtained his $\mathrm{PhD}$ in Chemistry at Mumbai University and is a Scientific Officer in the Applied Chemistry Division of BARC. His research interests include carbon monoxide oxidation over supported gold catalysts, and the development of catalyst-based sealed-off lasers.

\section{REFERENCES}

1 M. Haruta, T. Kobayashi, H. Sano and N. Yamada, Chem. Lett.,1987, 405

2 M. Haruta, N. Yamada, T. Kobayashi and S. Iijima, J. Catal., 1989, 115, 301

3 S. Tsubota, D.A.H. Cunningham, Y. Bando and M. Haruta, in 'Preparation of Catalysts VI', ed. G. Poncelet et al., Elsevier, Amsterdam, 1995, p. 227

4 M. Haruta, S. Tsubota, T. Kobayashi, M. Kageyama, M.J. Genet and B. Delmon, J. Catal., 1993, 144, 175

5 G.C. Bond and D.T. Thompson, Catal. Rev. -Sci. Eng., 1999, 41, 319

6 'The Abilities and Potential of Gold as a Catalyst' - Report of the Osaka National Research Institute (ONRI) No.393, August, 1999

7 M.J. Kahlich, H.A. Gasteiger and R.J. Behm, J. Catal., 1999, 182, 430

8 J.Jia, K. Haraki, J.N. Kondo, K. Domen and K. Tamaru, J. Phys. Chem. B, 2000, 104, 11153

9 C. Milone, R. Ingoglia, G. Neri, A. Pistone and S. Galvagno, Appl. Catal. A : General, 2001, 211, 251

10 S. Miao and Y. Deng, Appl. Catal. B: Environmental, 2001, 31, L1-L4

11 M. Bonarowska, A. Malinowski, W. Juszczyk and Z. Karpinski, Appl. Catalysis B: Environmental, 2001, 30, 187
12 R.J.H. Grisel and B.E. Nieuwenhuys, J. Catal., 2001, 199, 48

13 D. Andreeva, T. Tabakova, L. Ilieva, A. Naydenov, D. Mehanjiev and M.V. Abrashev, Appl. Catal. A : General, 2001, 209, 291

14 C. Baratto, G. Sberveglieri, E. Comini, G. Faglia, G. Benussi, V. La Ferrara, L. Quercia, G. Di Francia, V. Guidi, D. Vincenzi, D. Boscarino and V. Rigato, Sensors and Actuators $B, 2001, \mathbf{6 8}, 74$

15 A.K. Tripathi, N.M. Gupta, U.K. Chatterjee and D.D. Bhawalkar, Rev. Sci. Instrum., $1994,65,3853$

16 A.K. Tripathi, N.M. Gupta, U.K. Chatterjee and R.M. Iyer, Ind. J. Technol., 1992, 30, 107

17 S.D. Gardner, G.B. Hoflund, D.R. Schryer, J. Schryer, B.T. Upchurch and D.R. Brown, in 'Low Temperature CO Oxidation Catalysts for Long-Life $\mathrm{CO}_{2}$ lasers', ed., D.R. Schryer and G.B. Hoflund, NASA Conference Publication No. 3076, 1990, p. 123

18 F. Boccuzzi, A. Chiorino, S. Tsubota and M. Haruta, J. Phys. Chem., 1996, 100, 3625

19 F. Boccuzzi, A. Chiorino, S. Tsubota and M. Haruta, Catal. Lett., 1994, 29, 225

20 M.A. Bollinger and M.A. Vannice, Appl. Catal. (B), 1996, 8, 417

21 A. Knell, P. Barnickel, A. Baiker and A. Wokaun, J. Catal., 1992, 137, 306

22 A.M. Visco, A.Donato, C.Milone and S. Galvagno, React. Kinet. Catal. Lett., 1997, 61, 219

23 T.M. Salama, T. Shido, H. Minagawa, and M. Ichikawa, J. Catal., 1995, 152, 322

24 D.A.H. Cunningham, W. Vogel, H. Kageyama, S. Tsutoba and M. Haruta, J. Catal., $1998,177,1$

25 F. Boccuzzi and A. Chiorino, J. Phys. Chem. B, 2000, 104, 5414

26 T. Tabakova, V. Idakiev, D. Andreeva and I. Mitov, Appl. Catal., 2000, 202, 91

27 Y. -S.Su, M.-Y, Lee and A.D. Lin, Catal. Lett., 1999, 57, 49

28 M. Haruta, Catal. Today, 1997, 36, 153

29 W. Valden, X.Lai and D.W. Goodman, Science, 1998, 281, 1647.

30 L. Guczi, D. Horváth, Z. Pászti, L. Tóth, Z.E. Horváth, A.Karacs and G. Petô, J. Phys. Chem. B, 2000, 104, 3183

31 J.-D. Grunwaldt, M. Maciejewski, O.S. Becker, P. Fabrizioli and A. Baiker, J. Catal. 1999, 186, 458

32 G.C. Bond and D.T. Thompson, Gold Bull. 2000, 33, 41

33 A.I. Kozlov, A.P. Kozlova, H. Liu and Y. Iwasawa, Appl. Catal. A. Gen., 1999, 182, 9

34 N.D. Gangal, N.M. Gupta and R.M. Iyer, J. Catal., 1990, 126, 13

35 N.D. Gangal, N.M. Gupta and R.M. Iyer, J. Catal., 1993, 140, 443

36 A.K. Tripathi and N.M. Gupta, J. Catal., 1995, 153, 208

37 V.P. Londhe and N.M. Gupta, J. Catal., 1997, 169, 415

38 A.K. Tripathi, V.S. Kamble and N.M. Gupta, J. Catal., 1999, 187, 332

39 N.M. Gupta and A.K. Tripathi, J. Catal., 1999, 187, 343

40 A.K. Tripathi, Ph.D. Thesis, Mumbai University, 1999

41 V.P. Londhe, V.S. Kamble and N.M. Gupta, J. Mol. Catal. A : Chemical, 1997, 121, 33

42 N.M. Gupta, V.S. Kamble, V.B. Kartha, R.M. Iyer, K.R. Thampi and M. Gratzel, J. Catal., 1994, 146, 173

43 F. Solymosi and J. Rasko, J. Catal., 1989, 115, 107

44 N.M. Gupta and A.K. Tripathi, unpublished work

45 W.S. Epling, G.B. Hoflund, J.F. Weaver, S. Tsubota and M. Haruta, J. Phys. Chem., 1996, 100, 9929

46 D. Horváth, L. Tóth and L. Guczi, Catal. Lett., 2000, 67, 117

47 M. Che and C.O. Bennett, in Advances in Catalysis, ed., D.D. Eley, H. Pines and P.B. Weisz, Vol.36, p.76, Acad. Press, San Diego, CA, 1989

48 G.A. Somorjai in 'Introduction to Surface Chemistry and Catalysis', John Wiley, New York, 1994, p. 442 